\title{
Variations in Implementing Sustained-Yield Forestry in Canada-Quebec
}

\section{J. Harry G. Smith}

Professor, Faculty of Forestry

University of British Columbia

Vancouver, B.C. V6T 1W5

\section{Abstract}

The situation to 1974 is described briefly. Effects of legislation implemented in 1975 are not entirely clear, but progress has been made by the Quebec government on forest use zoning, encouraging farm forestry, rationalizing wood use by industry, taking control of management of timber limits, and negotiating compensation and timber supply agreements. Resource allocation and management planning are the subject of intense efforts by a task force of specialists from many areas. It is expected that their plans will be completed for management of 44 units covering all of Quebec's forests by 1980.

By 1982 all timber limit areas are to be managed by the Quebec Department of Lands and Forests. Wood will be made available on a volume allotment basis for 10-year, once renewable, terms. Stumpage charges may be variable.
\end{abstract}

\section{Résumé}

La situation, jusqu'en 1974 est brièvement décrite. Les effets de la législation adoptée en 1975 ne sont pas entièrement clairs, mais le gouvernement du Québec a progressé dans le zonage de l'utilisation forestière, en encourageant les fermes forestières, en rationalisant l'utilisation du bois par l'industrie, en prenant le contrôle de l'aménagement des concessions forestières et en négociant des ententes sur les compensations et l'approvisionnement en bois. L'allocation des ressources et la planification de l'aménagement font l'objet d'efforts intenses de la part d'une équipe de travail composée de spécialistes de plusieurs disciplines. On s'attend à ce que leurs plans d'aménagement de 44 unités, recouvrant toutes les forêts du Québec, soient terminés pour 1980.

En 1982, toutes les concessions forestières seront gérées par le ministère québécois des Terres et Forêts. L'allocation du bois sera faite sur une base volumétrique par le biais de contrats de 10 ans, renouvelables une fois. Les droits de coupe peuvent varier.

1Prepared for the Western Forest Economists meeting. Wemme, Oregon, May 3-5, 1976. Comments by Dr. L. J. Lussier, Director of COGEF and by Dr. J. P. Nadeau, Chairman CCREM Task Force on Forest Policies, Quebec, are very much appreciated.

\section{Introduction}

My interest in forest land management in Quebec has been based upon many pleasant contacts through National meetings and various associations with the students and staff of Laval University. Obviously, you will regret that Dr. Nadeau is not here to tell you first hand about his Province but I will do my best to interpret from afar what is going on there.

In order to establish some dimensions to what I know about implementing sustained yield forestry in Quebec, I will mention some background documents. (Munro 1971) included Quebec in a review of Canadian forest regulation methods and management objectives that he summarized for me. Gilles Lessard and I collaborated in a background study of forest resources research in Canada (Smith and Lessard, 1971) that included some developments in Quebec. (Naysmith 1975) reviewed land use and public policy in Northern Canada, and much of that has implications for parts of Quebec. (Thomas 1975) is involved in a major Canadian Forestry Service effort to develop interest in formulation of a national forestry policy. In 1976, under the Canadian Council of Resources and Environment Ministers, a Task Force on forest policies has been (1) identifying forest policies, major problems and major issues, and (2) analyzing trends in policies in various Canadian jurisdictions. Forest resources and utilization in Canada to the year 2000 have been estimated from a 1968 base by (Manning and Grinnell 1971). Location, delivered cost, and product suitability of Canada's surplus timber have been documented effectively by (Reed and Associates 1973). Their study should be expanded to provide current information on trends in withdrawals, economic accessibility, complete tree and full stand utilization, average yields and biological potentials for forest production and the further increases potentially available from intensive management. Since Quebec still does not have a complete forest inventory it is difficult to put any national study into a correct perspective.

Quebec is a large, heavily forested Province. Of its total land area, 361.6 million acres (146.4 million ha), $79.8 \%$ is forested, 288 million acres (116.6 million ha). Public forest resources account for $85 \%$ of the total productive forest land. Present timber harvests total one billion cubic feet $\left(28\right.$ million $\mathrm{m}^{3}$ ) but average only about 15 cubic feet per productive acre $\left(1.05 \mathrm{~m}^{3} / \mathrm{ha}\right)$, and are taken from increasingly poorer and more remote forests (Lachance 1970). 
The major areas of interest today are revocation of timber limits, establishment of forest use zoning, encouragement of management of private lands, development of forest credit systems, strengthening of agencies for research, insistence upon high levels of professional standards, and conflicting pressures from unions.

\section{The Situation to 1974}

The U.B.C. Faculty of Forestry has followed events in Quebec with much interest. The second H. R. MacMillan Lecture, by John D. Gilmour, a strong advocate of industrial forestry, described the forest situation in the Province of Quebec as of 1951 (Gilmour, 1951).

Gilmour observed that from 1920 to 1950 nearly 8 million acres ( 3.24 million ha) had been taken out of the most accessible and best parts of unlogged timber licenses for colonization purposes. In vain attempts to establish permanent agricultural communities timber lands were cut off, cleared, and often much of the surrounding timbered country was burned before eventual abandonment.

The 24th H. R. MacMillan Lecture (Lafond, 1974) provided an excellent introduction to the forest types, forest industry, and legislation governing forest management and utilization in Quebec. Dean Lafond's Faculty at Laval University has taken the lead in demonstrating how far foresters can be educated and persuaded to improve the quality of management of their lands. He has estimated that if 35 cubic feet per acre $\left(2.45 \mathrm{~m}^{3} / \mathrm{ha}\right)$ can be grown on the productive portions of 27,000 square miles $\left(69.920 \mathrm{~km}^{2}\right)$ of private forests in Quebec, their yield would be 11 million cunits of wood, which is more than what is now harvested annually from the whole of Quebec. An impressive start has been made by more than 1,000 farm owners who have agreed to follow for a 10-year period the prescriptions prepared by the Laval Research Foundation for harvesting and restoration of their forest properties by silvicultural methods.

Dean Lafond has summarized the situation very well to 1974 in the following statement.

"The better known new trends in forest policy in Quebec can be found in a publication referred to as the "Green Book" published by the Provincial Government and the Department of Lands and Forests, entitled "Exposé sur la Politique forestière", Volume II - Réforme et Programme d'action, 1971. In this book some sweeping changes are proposed for the administration and management of Quebec forest lands. The general tendency is to give predominance to the Government in controlling management and logging of all forest lands. There is no doubt fundamental changes are needed in legislation and policies which for the most part were introduced in 1849, along with piecemeal and sometimes uncoordinated legislation added through the years. Distribution of timber limits in relation to users and in relation to industry is certainly a very serious and basic problem in certain cases increasing the cost of wood and thereby creating further difficulties for the stabilization of the smaller industries in several regions.

Two main points were presented in this very elaborate plan of action. First, all the timber limits would be abolished and replaced by domainal forests on which the users would have guaranteed access to the wood for a limited period of time. The development, the management and even the logging plan would be prepared under Government direction. Secondly, it was proposed that a large Association to be named the "Société de Gestion forestière" would be responsible for the coordination of all logging in the Province of Quebec. Emphasis also would be given to the restoration and management of small private forest lands.

This brought very strong and adverse reactions from the industry. The Minister of Lands and Forests decided that the idea of the "Société de Gestion forestière" should be abandoned for the time being and that transformation and liquidation of timber limits would be done over a period of ten years. Negotiations are taking place with some companies, in order to find the best way this could be effected. Otherwise, no major legislation has been introduced to apply these sweeping changes to the management of the Quebec forest lands. However, some legislation concerning the zoning of forest lands is expected soon as well as some very important bills pertaining to management and development of private woodlands and forests."

In 1975 legislation was passed to put all of these changes into effect (Financial Post 1975, van Dusen, 1975a, b).

A major justification for taking over the timber limits by the Province (retrocession) has been the desire to rationalize the structure of the forest industry. Industry certainly needed and sought help (PPMC, 1972) but didn't get what it hoped for.

Lussier, a long time consulting forester who now heads the Task Force responsible for planning, foresaw in 1970 what should be done to make better use of Quebec's forest resources. He gained much support for his aggressive justification of investments in reforestation and intensification of management. Although conventional economic analyses showed only $1-4 \%$ profit, he found that "with state financial participation, the rate of rentability of forest investments was of about $50 \%$ for the individuals and of $25 \%$ for the province" (Lussier 1970) stressed the gains from provision of jobs and sought a redistribution of benefits from investments. Obviously his findings were persuasive to the Province. In many parts of Quebec there are lesser developed regions to which forestry can contribute significantly, but there still are many arguments about the ends and the means (Haley and Smith, 1971).

\section{Revocation of Limits}

As of 1974, 88 limit holders held timber rights to 55.7 million acres (22.6 million ha). Eight companies controlled 49.2 million acres (19.9 million ha). The largest, Canadian International Paper had timber rights on 14.1 million acres ( 5.7 million ha). 
Annual rent was 3.125 cents per acre, fire control was required, and stumpage was charged at $\$ 5.00$ per cunit $\left(\$ 1.77 / \mathrm{m}^{3}\right)$.

The first limits to be taken over by the Quebec Department of Lands and Forests were those of the Canadian International Paper Company (CIP) in N.W. Quebec, which held 4.3 million acres $(1.74$ million ha) in a single major timbershed. About $\$ 2$ million was offered to CIP to compensate for the depreciated cost of investments in roads and camps.

CIP had cutting rights to 600,000 cunits (1 $698000 \mathrm{~m}^{3}$ ) but these were reduced to 450,000 $\left(1273500 \mathrm{~m}^{3}\right.$ ) and the rest will have to be bought as chips from sawmills.

It is expected that $\$ 70$ million will be required over the period ending in 1982 to compensate limit $\approx$ holders for their depreciated historical costs for roads, bridges and facilities they have built and i maintained.

Wood supply agreements are being negotiated individually with each company. They are for 20 years, renewable every 10 years, thereafter. They define cutting areas and require yearly approval of cutting plans. Roads will be built and maintained by Government, and all forestry will be done by Government at a cost estimated to be at least $\$ 2.00$ a cunit $\left(70 \varnothing\right.$ per $\left.\mathrm{m}^{3}\right)$. Road use and forest management charges will be levied by the Province. Stumpage charges may be changed from a single price to one based in part upon varying Wogging chances and distances from mills.

As of February 21, 1976 under the Quebec Offiial Languages Act, all applications for timber sup. French.

During the process of rationalizing wood supply, cutting areas, volumes, species and grades will be allocated to make more efficient use of existing timber resources. Companies will not be granted rights to roundwood until they have taken up their prescribed share of chips

The present situation in Quebec may have resulted in part from the insecurity of annually renewable limits and from an excess of regulation with few incentives and very little attention to forest regeneration and multiple use. (Gilmour 1951) described the situation as follows

"Since about 1921 the laws of the Province have insisted that all licences and leases must be operated under the provisions of working-plans, which must be approved and policed by Government foresters. These plans must be revised and kept up to date. This legislation has been enforced faithfully for 30 years, and has prevented overcutting on all areas to which it applies... When timber is cut on licences, according to the provisions of the working-plan which applies to the area, it is scaled by licences scalers, and royalties are paid on it at rates which the government sets from time to time... The same rate has applied to all species, wherever situated ... even when the time comes to make a second or later cut from timber which has been grown during the tenancy of the licensee, royalties still apply. No one knows what these rates, to be set by some future Government, may be. They may account for the licensee's entire equity in the stumpage value, leaving no return whatever for the money, the time, and the risk he incurred in growing the new crop. Under these conditions, no one can justify any unnecessary expenditure today, even though he knows that to do so would lead to considerably increased growth. That is the real obstacle to forest management in every province in which there is a timber royalty rather than a simple tax on forest land."

For a long while it has been obvious that there were major problems in Quebec's forests and forest industry. The failure of colonization projects to establish viable agricultural communities, the reluctance of the pulp industry to buy farm wood at the price it cost to produce wood from their limits, the average hauling distance of 156 miles to pulp mills, all created severe problems.

In 1972 the Government offered the following 10 reasons to justify the takeover (Royer, 1975):

1. Multiplicity, dispersion and smallness of the management units.

2. Presence of enclaves.

3. Irrational carving up of limits and non-coincidence of timber limit lines and the boundaries of hydrographic watersheds.

4. Existence of forest monopolies.

5. Incomplete utilization of the softwood resource.

6. Incomplete utilization and freezing of the hardwood resource.

7. Increased forest productivity.

8. Multiple use of the forests.

9. Development of the over-all responsibility of the Province.

10. Need for reducing the cost of the wood.

Although Royer could counter most of these points quite effectively, there has been little Public sympathy for his position. In a period of much social unrest, great concern for the environment, and strident Nationalism on behalf of Canada (Smith, 1975) and for preservation of French rights within Quebec, pressures for re-assertion of the Public interest were overwhelming.

\section{Zoning}

The government will set aside lands in zones for four major purposes (Pouliot, 1975). The production forests will be established to serve industrial wood needs for the length of a rotation. The protection forests will help stabilize soil and control water, aided by carefully controlled logging. Recreation forests will involve either partial or total restrictions on logging and may be administered by recreational bodies or municipalities for recreation as the primary use. Zones of a relatively small area, ecological reserves, will preserve particular vegetation types.

Following zoning, timber limits and township reserves will be gradually abolished during the period ending in 1982. New management units will be formed to take into account the location and the relative importance of the mills they should 
supply, the complexity and the productivity of the forest stands and the needs for more or less intensive silvicultural operations (Pouliot, 1975).

\section{Domainal Forests}

These state reserves are managed according to well defined rules. In 1973 they totalled 57.9 million acres (23.5 million ha) and supported a cut of 1.8 million cunits $\left(5.1\right.$ million $\left.\mathrm{m}^{3}\right)$ for 58 different industries. Some logging is done by a Provincial government company, Rexfor. On the largest portion, 32 million acres (12.9 million ha), Rayonier Canada plans the logging but the Government builds roads and prepares management plans.

It is likely that all of the revoked limits will also be managed as domainal forests. We all should hope that their management will be improved since, as recently as June 20,1972, the Minister of Lands and Forests "declared that nothing was ever so badly run as the domainal forests then in existence" (Royer, 1975).

\section{Funds and Methods for Private Forest Management}

Forest credit for up to 60 years is to be provided to purchase land, improve wood lots, and finance capital projects undertaken by private owners of forest land. The Farm Credit Bureau will be authorized to loan up to $90 \%$ of the value of the timber lands.

These private forests comprise only about $10 \%$ of the total forest land area but contribute from 20 to $25 \%$ of the wood harvested, annually. Although they produce valuable forest products in addition to wood, and are relatively easily accessible along the St. Lawrence River, some major problems must be overcome. Pouliot (1975) has noted their disposition, their small areas, the great number of owners (about 160,000), and the lack of ability, information, and incentive to manage their forests. The first approach has been made to re-grouping of Producers Associations into Regional Silvicultural Associations. A massive effort is being made to educate owners and revitalize wood lot management in order to increase timber harvests and provide employment.

\section{Control of Professional Standards}

Unionization and rising public concerns about professional qualifications and status are leading to many changes in Quebec's Corporation of Forest Engineers.

As part of a Quebec-wide tightening of performance standards for professionals, the Corporation of Forest Engineers will have to maintain a detailed registry of its members, their qualifications, and the extent to which these are kept modern.

\section{Resource Allocation and Management Planning}

The new approach to forest resource allocation and management in Quebec was described by
(Lussier 1976). By 1980, 44 management units are to be planned. The main sectors of activities being considered by Lussier's task force are shown in his Figure 1.

Fig. 1. Main Sectors of Activities
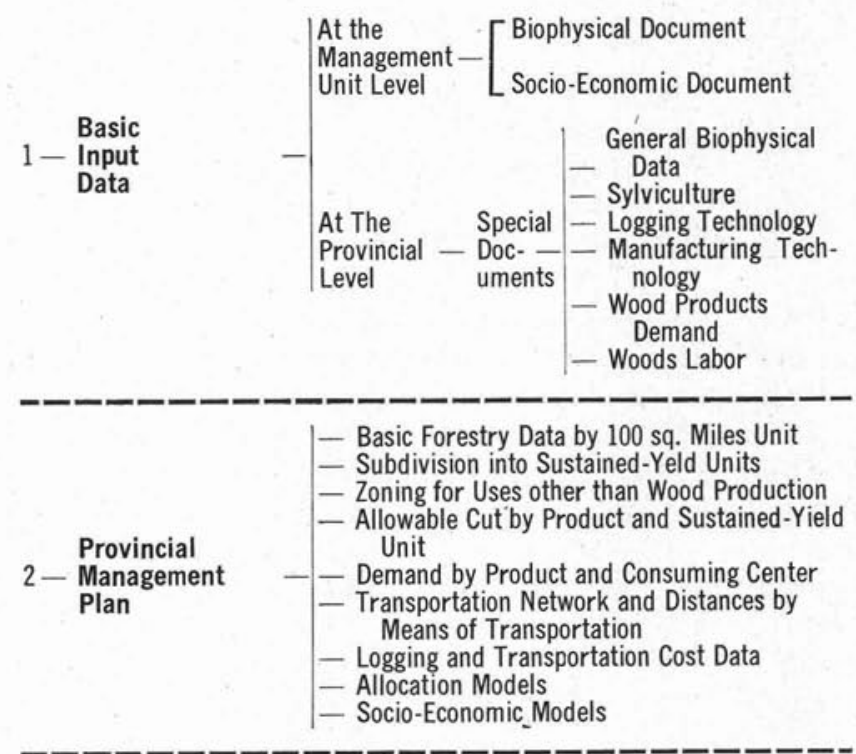

Analytical and
3- Decision-Making $-\begin{aligned} & \text { Models and Programs } \\ & \text { Process }\end{aligned}$

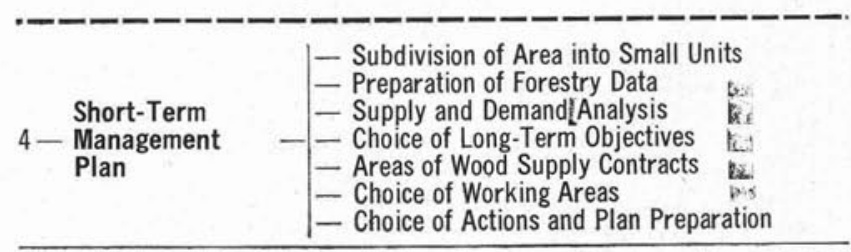

Figure 1 is from "A new approach to forest resource allocation and management in Quebec" presented to the March, 1976 meeting of the Woodlands Section of the Canadian Pulp and Paper Association in Montreal by L.!J! Lussier, Director of COGFF. (Pulp and Paper Canada 77 (7):42-51).

\section{Research and Development}

The search for new and different approaches has been extended into forest research. The Council on Forestry Research and Development was established by a 1969 Act to advise the Minister of Lands and Forests. It reported annually and accomplished much in five years. In 1975 following a thorough review of research needs and opportunities and the best way to serve them (Council of Forestry Research and Development, 1975), the Council resigned in the hopes that it would be reconstituted in a proposed new form. The research advisory function now is consolidated with a general forestry advisory group for a period of several years while the new forest policy is being worked out. It is likely that during the transition to direct government management there will not be much surplus time for planning better research and development. 


\section{Union Reactions}

Producers unions and farm forestry cooperators are enthusiastic as are the mostly non unionized small sawmill operations. (Van Dusen 1975b) forecast problems from the policy of "small sawmills first" which appears to work against the fully unionized operations of the major producers.

Since government unions are very strong in Quebec, problems may also develop in formulation of agreements for land management activities.

\section{Concluding Discussion}

No doubt many changes were badly needed but only time will tell whether or not Quebec will find the money and develop the knowledge and experience needed to improve utilization and intensify forest management.

At present there are no plans for further direct government involvement in manufacturing, but more cooperative joint ventures could ensue.

I regret the lack of industrial performance in forest management, and expect that inefficiencies will arise through lack of incentives for high productivity in government operations. The Quebec Department of Lands and Forests has a unique opportunity to practise good utilization, to intensify forest management, and to encourage farm forestry. Their task is formidable. I sincerely hope they can improve forestry in Quebec by concentrating management responsibility, rationalising wood supply, reducing wood costs and improving resource allocations.

\section{References}

Financial Post, March 15, 1975. Uneasy transition for woodlot management. p C 10.

Gilmour, J. G. 1951. The forest situation in the Province of Quebec. Univ. of B.C., Fac. of For. H. R. MacMillan Lecture No. 2,14 p.

Haley, D. and J. H. G. Smith. 1971. Justification and sources for funding of forestry operations in developing economies. Univ. of B.C. Fac. of For., 25 p. (1976, U. K. For. Comm. Bull. 56: 62-70).

Lachance, P. E. 1970. What do we know about the forest of Quebec? Can. Pulp and Paper Ind., Mar., 36-9.

Lafond, A. 1974. Forests and forestry in Quebec. Univ. of B.C., Fac. of For., H. R. MacMillan Lecture 24, 24 p.

Lussier, L. J. 1970. How Quebec can make better use of forest resources. Can. Pulp and Paper Ind., 33-6.

Lussier, L. J. 1976. A new approach to forest resource allocation and management in Quebec. Woodlands Sect., CPPA, Montreal, 25 p. (Pulp and Paper Canada 77 (7): 42-51).

Manning, G. H. and H. R. Grinnell. 1971. Forest resources and utilization in Canada to the year 2000. Canadian Forestry Service, Ottawa, No. 1304, 80 p.

Munro, J. A. 1971. Review of Canadian forest regulation methods and management objectives. Univ. of B.C. Fac. of For., mimeo.

Naysmith, J. K. 1975. Land use and public policy in northern Canada. Univ. of B.C., Fac. of For., Ph.D. thesis, 396 p.

Pouliot, J. M. 1975. Recent policy developments in the Province of Quebec. In Woodlands Section, CPPA, Montreal, W. S. Index 2761, 45-54.

Pulp and Paper Mag. of Can. April, 1972. Immediate government action required. p. 16.

Reed, F. L. C. and Associates. 1973. Canada's reserve timber supply: The location, delivered cost and product suitability of Canada's surplus timber. Dept. of Industry Trade and Commerce, Ottawa, $195 \mathrm{p}+$ App.

Royer, R. 1975. Comment. In Woodlands Section, CPPA, Montreal, W.S. Index 2671, 54-65.

Smith, J. H. G. 1975. Constructive capitalism can compete. Univ. of B.C., Fac. of For., 14 p. (Western Forestry and Conservation Association Proceedings 1976: 64-67).

Smith, J. H. G. and G. Lessard. 1971. Forest resources research in Canada. Science Council of Canada, Ottawa, Spec. Study 14, 204 p.

Thomas, P. 1976. Progress report on development of a National forestry policy. Canadian Forestry Service, Ottawa.

Van Dusen, M. September 13, 1975. How management plans in East are changing. The Financial Post. p. 13.

Van Dusen, M. November 15, 1975. Quebec's plans for forests could raise newsprint price. The Financial Post, p. 13.
YUKON FORESTRY SERVICE LIBRARY requires

the following issues of FORESTRY CHRONICLE

$\begin{array}{lll}\text { September } & 1929 & \text { No. } 3 \\ \text { December } & 1929 & \text { No. } 4 \\ \text { February } & 1930 & \text { No. } 1 \\ \text { December } & 1930 & \text { No. } 4 \\ \text { June } & 1933 & \text { No. } 2\end{array}$

Send Replies to:

YUKON LANDS \& FOREST SERVICE

200 Range Road, Whitehorse, Y.T. Y1A 3V1 Attn.: E. Nyland, Superintendent

\section{Woodlot Service Ltd.}

"All Matters Pertaining to Forestry"

GORDON B. YOUNG, B.Sc.F., M.F.

Registered Professional Forester

320 Maple Street

Bus.: $506-472-3396$

Fredericton, N.B.

Home: 506 - 472-7721 